\title{
Chapter 27 \\ If We Want to Get Ahead, We Should \\ Transcend Dualisms and Foster \\ Paradigm Pluralism
}

\author{
Thorsten Scheiner
}

\begin{abstract}
In this chapter, I argue for the importance of transcending dualisms and using multi-paradigm perspectives when examining phenomena and issues in mathematics education. I begin by exploring the philosophical bases-ontological, epistemological, axiological, and methodological-underlying three major paradigms in mathematics education research: the modernist (post-)positivist paradigm, the post-modernist interpretive paradigm, and the post-modernist transformative paradigm. Then, I present three modes of thinking that enable researchers to deal with multiple paradigms: dualistic thinking, dialogical thinking, and dialectical thinking. I adopt the dialectical mode of thinking to blend the modernist and post-modernist paradigms with respect to an ontological opposition (mind-world duality) and an epistemological opposition (objectivity-subjectivity duality) prevalent in the literature. A new paradigm begins to emerge from this blend, one which transcends these dualities to better interpret phenomena and issues in mathematics education.
\end{abstract}

Keywords Paradigm - Mathematics education research - Pluralism • Multi-paradigm inquiry $\cdot$ Blending $\cdot$ Transcending dualisms

Following diSessa (1991) and Schoenfeld (2014) this chapter takes as its point of departure Karmiloff-Smith and Inhelder's (1974/75) well-known paper If you want to get ahead, get a theory. In his paper, If we want to get ahead, we should get some theories, diSessa (1991) argued for serious dedication toward theory advancement in mathematics education, as we have not yet reached deep theoretical understanding of knowledge or the learning process. In his paper, If you really want to get ahead, get a bunch of theories ... and data to test them, Schoenfeld (2014) called for approaching complex issues in mathematics education from multiple theoretical perspectives and at multiple levels of granularity. In this chapter, I intend to contribute to this conversation by arguing for conducting multi-paradigm inquiry and blending paradigmatic controversies. Such an approach moves the field beyond dualisms that hinder theoretical discourse.

T. Scheiner $(\bowtie)$

Institute for Learning Sciences \& Teacher Education, Australian Catholic University,

Brisbane, Australia

e-mail: thorsten.scheiner@acu.edu.au

The University of Auckland, Auckland, New Zealand

(C) The Author(s) 2019

G. Kaiser and N. Presmeg (eds.), Compendium for Early Career

Researchers in Mathematics Education, ICME-13 Monographs,

https://doi.org/10.1007/978-3-030-15636-7_27 


\subsection{Introduction}

Mathematics education has become an independent research field that draws insights, perspectives, and methods from a variety of other fields, including anthropology, cognitive science, education, history, linguistics, mathematics, philosophy, psychology, semiotics, and sociology. Thus, it is not surprising that a diversity of theoretical and philosophical bases underpins mathematics education research. Indeed, this diversity of theoretical and philosophical bases serves to strengthen the field (Cobb 2007). Nevertheless, when conducting mathematics education research, it is necessary to carefully select and justify appropriate theoretical and philosophical bases. Indeed, mathematics education research is undertaken for a variety of reasons, including understanding and explaining phenomena in mathematical knowing, learning, and teaching; exposing and challenging the social and political frames in which mathematics education come about; and empowering individuals involved in the broader educational context. The exact purpose and nature of research are influenced by the researcher's ways of looking at the world: that is, they are influenced by the researcher's paradigm. A paradigm is a way of viewing the world that reflects fundamental philosophical assumptions that guide and direct thinking and action.

The perspective taken here is that our paradigms frame our inquiries, and indeed lives, by giving shape and meaning to the world we experience and act within. Indeed, a researcher's worldview not only underlies his or her choice of what phenomena to study but has implications for the choice of method when studying the phenomena. Such choices are based on fundamental assumptions about the nature of the phenomena and the nature of knowledge about the phenomena. Some researchers do not explicitly acknowledge the fundamental philosophical assumptions underlying their research; this does not mean that such assumptions do not exist, but rather that their research relies on implicit, and partially unrecognized or unexamined, assumptions. However, in order to make sensible decisions when planning and conducting research, be mindful in reading and critiquing research, and contribute productively to the theoretical and methodological debates in the research community, one needs to recognize and understand the fundamental philosophical assumptions underpinning one's study. In summary, researchers should identify their views of the world and acknowledge the way these views "orient and constrain the types of questions that are asked about the learning and teaching of mathematics, and thus the nature of the phenomena that are investigated and the forms of knowledge produced" (Cobb 2007, p. 7). Being explicit in recognizing one's own paradigm enables a researcher to become a more reflective practitioner and allows researchers to recognize the constraints of their sense-making of phenomena under consideration.

Over the past few decades there has been a remarkable growth, within the mathematics education research community, in the recognition of and discussion about: diverse theoretical and philosophical positions (Ernest 1991; Sierpinska and Kilpatrick 1998; Sriraman and English 2010); various methodologies 
(Bikner-Ahsbahs et al. 2015; Kelly and Lesh 2000; Schoenfeld 2008); and central educational dimensions (e.g., critical, cultural, political, and social) (Jablonka et al. 2013; Rogers and Kaiser 1995; Skovsmose 1994). Scholars in our field have been debating the distinctive contributions of, and to, knowledge that arise from different research paradigms (Ernest 1998). This debate is perhaps most succinctly characterized by examining different fundamental assumptions about the nature of the world (ontology), the nature of knowledge about the world (epistemology), the nature of ways of studying phenomena in the world (methodology), and the value of knowledge, including ethical concerns (axiology). These fundamental philosophical assumptions (ontological, epistemological, methodological, and axiological) are arguably the core bases used (and disputed) amongst different paradigms (Lincoln et al. 2011). Ernest (2012), for example, positioned ethics as a first philosophy for mathematics education, as it "enters into mathematics education research in several ways" (p. 13) and enables one "to rethink and reevaluate some of the taken-for-granted commonplaces of our practices" (p. 14), which opens up new possibilities for the advancement of the field.

Mathematics education research today is "very multi-faceted and highly diverse" (Niss 2018, p. 41) and is "decidedly not in a period of normal science" (Schoenfeld 1992, p. 180), but instead is shaped and underpinned by a variety of different paradigms. Trying to identify all the paradigms that underpin and shape research and practice in mathematics education is impossible, and conceivably less useful than identifying the major paradigms within which many researchers, knowingly or unknowingly, situate themselves. In this chapter I consider three such paradigms that embody fundamental differences in understanding the nature of inquiry in mathematics education.

The purpose of this chapter is to provide researchers with an opportunity to reflect on and reframe their own paradigms (see Schön and Rein 1994) and, even more importantly, an opportunity to bring diverse paradigms into productive interplay. In Sect. 27.2, I outline three major paradigms in mathematics education research, allowing researchers to identify the paradigm most aligned with their own, as well as to examine dominant worldviews and how they shape the way researchers think. Rather than encouraging researchers to choose from these seemingly-opposed paradigms, I propose in Sect. 27.3 different ways of dealing with these paradigms. In particular, three modes of thinking are outlined: dualistic thinking, dialogical thinking, and dialectical thinking. Dualistic thinking divides philosophical assumptions underlying different paradigms into polar opposite positions and allows privileging one side of the dualism. Dialogical thinking entertains different - even opposing — views simultaneously, and thereby develops richer accounts of phenomena that better reflect their complexity, paradoxes, and ambiguities. Dialectical thinking seeks to transcend dualism by blending opposing positions to arrive at a comprehensive view of the phenomena under consideration.

In Sect. 27.4, I coordinate seemingly opposing philosophical assumptions underlying critical paradigms in such a way as to provide new possibilities for reframing our view of the world. Finally, I conclude in Sect. 27.5 with some reflections and further considerations of these modes of thinking-for better 
understanding the complexities, recognizing the paradoxes, and appreciating the ambiguities inherent in the multi-faceted phenomena and diverse issues in mathematics education.

\subsection{Delineating Major Paradigms That Underpin Mathematics Education Research}

Paradigms are overarching frameworks that shape our whole approach to being in the world (Kuhn 1962): they shape our perceptions, conceptions, and actions. Kuhn (1962), for instance, showed that normal scientific research takes place within such an overarching framework and that various forces work to cohere (consciously and unconsciously) the fundamental philosophical assumptions of the framework. However, from time to time the overarching framework shifts in revolutionary fashion as new philosophical assumptions are used to make better sense of particular phenomena.

Nowadays various such overarching frameworks underpin mathematics education research. The purpose here is not to judge, but to elucidate the philosophical assumptions of these paradigms. The overarching frameworks under consideration in this section are the positivist paradigm and its successor the post-positivist paradigm (that are often referred to as modernist worldviews) as well as the interpretive paradigm and the transformative paradigm (that are often referred to as post-modernist worldviews). ${ }^{1}$

Higginson (1980) argued that

[a]1l [human] intellectual activity is based on some set of assumptions of a philosophical type. [...] Reduced to their essence these assumptions deal with concerns such as the nature of 'knowledge', 'being', 'good', 'beauty', 'purpose' and 'value'. More formally we have, respectively, the fields of epistemology, ontology, ethics, aesthetics, teleology and axiology. More generally we have issues of truth, certainty and logical consistency. (p. 4)

\footnotetext{
${ }^{1}$ Indeed, there is a variety of paradigmatic strands in mathematics education research. Focusing on the (post-)positivist, interpretive, and transformative paradigms is not meant exhaustively list all possible paradigms underpinning mathematics education research, but rather to accentuate major, seemingly opposing positions in the literature. These paradigms represent broad camps within which many schools of thought and subtle variations flourish. These paradigms also indicate decisive shifts and historical moments of mathematics education research, including the process-product moment (with its aim of predicting phenomena), the interpretivist-constructivist moment (with its aim of understanding phenomena), the social-turn moment (with its aim of understanding the situatedness of phenomena), and the socio-political-turn moment (with its aim of emancipation and deconstruction) (Stinson and Bullock 2012).

Notice that there is no universally agreed upon way to divide up the schools of thought; neither the labels (or terms) of these paradigms nor the lines between them are altogether clear. Different terms have been used for describing each paradigm. For example, the (post-)positivist paradigm has been referred to as the "conventional paradigm" (Galbraith 1993) or the "scientific paradigm" (Habermas 1972).
} 
For the purposes of this chapter, the focus is on the ontological, epistemological, axiological, and methodological bases of a paradigm. In summary:

- the ontological base concerns issues about the nature of reality or being in itself (e.g., 'What is the nature of reality?');

- the epistemological base concerns issues about the nature of knowledge (including what forms of knowledge are considered as 'scientific') (e.g., 'What is the nature of knowledge and the relation between the knower and what can be known?');

- the axiological base concerns issues about values and ethics (e.g., 'What knowledge is intrinsically worthwhile and what is it about it that is valuable as an end in itself?'); and

- the methodological base concerns issues about ways of studying phenomena in the world (e.g., 'How can the knower obtain knowledge?').

These four methodological bases are intricately related and mutually informing. In the following subsections, the (post-)positivist, interpretive, and transformative paradigms are contrasted on the basis of their ontological, epistemological, axiological, and methodological assumptions. To do so, the more radical philosophical assumptions within each paradigm are foregrounded, not only because the controversies concerning their intellectual legitimacy often take place at the edges of those paradigms, but also because those edges are the intellectual, theoretical, and practical space for dialogue.

Table 27.1 lists assumptions that the (post-)positivist, interpretive, and transformative paradigms make about the nature of reality (ontology), the nature of knowledge (epistemology), the value of knowledge (axiology), and the nature of inquiry (methodology).

Table 27.1 Overview of fundamental philosophical assumptions underlying major paradigms ${ }^{\mathrm{a}}$

\begin{tabular}{l|l|l|l}
\hline & Modernist & Post-modernist \\
\hline Ontology & $\begin{array}{l}\text { (Post-)Positivist } \\
\text { Realism-'real' reality } \\
\text { that is independent of } \\
\text { and external to the } \\
\text { knower }\end{array}$ & $\begin{array}{l}\text { Relativism-multiple, } \\
\text { locally constructed } \\
\text { realities } \\
\text { (or: reality as an } \\
\text { (reality is knowable) } \\
\text { intersubjective social } \\
\text { Post-positivist: critical } \\
\text { realism (reality is only } \\
\text { imperfectly and } \\
\text { probabilistically } \\
\text { knowable) }\end{array}$ & $\begin{array}{l}\text { Relativism-various } \\
\text { versions of reality based } \\
\text { on, and shaped by, } \\
\text { cultural, social, political, } \\
\text { ethnic, and gender } \\
\text { values crystallized over } \\
\text { time }\end{array}$ \\
\hline
\end{tabular}


Table 27.1 (continued)

\begin{tabular}{l|l|l|l}
\hline & Modernist & \multicolumn{2}{l}{ Post-modernist } \\
\hline Epistemology & $\begin{array}{l}\text { Reality is discovered (or } \\
\text { uncovered); findings are } \\
\text { (probably) true; striving } \\
\text { for objectivity }\end{array}$ & $\begin{array}{l}\text { Reality is (socially) } \\
\text { constructed; findings are } \\
\text { created; acknowledging } \\
\text { subjectivity (or } \\
\text { inter-subjectivity) }\end{array}$ & $\begin{array}{l}\text { Knowledge is socially } \\
\text { and historically situated; } \\
\text { value mediated findings; } \\
\text { seeking objective } \\
\text { multi-perspectival } \\
\text { knowledge of all } \\
\text { participants }\end{array}$ \\
\hline Axiology & $\begin{array}{l}\text { Knowledge about the } \\
\text { world is an end in itself; } \\
\text { need to minimize harm; } \\
\text { informed consent; } \\
\text { respect for privacy }\end{array}$ & $\begin{array}{l}\text { Multi-perspectival } \\
\text { knowing is valuable as a } \\
\text { means for balancing } \\
\text { representations of views } \\
\text { and raising participants; } \\
\text { awareness }\end{array}$ & $\begin{array}{l}\text { Knowing is valuable as } \\
\text { a means for promoting } \\
\text { human rights and } \\
\text { increasing social justice; } \\
\text { need to address issues of } \\
\text { power and trust; respect } \\
\text { for cultural norms }\end{array}$ \\
\hline Methodology & $\begin{array}{l}\text { (Quasi-)experimental; } \\
\text { seeking general laws; } \\
\text { hypotheses-testing } \\
\text { (verification or } \\
\text { falsification of } \\
\text { hypotheses); mainly } \\
\text { quantitative methods }\end{array}$ & $\begin{array}{l}\text { Hermeneutical, } \\
\text { generative approaches; } \\
\text { case-study design; } \\
\text { mainly qualitative } \\
\text { methods }\end{array}$ & $\begin{array}{l}\text { Critical, reflexive, and } \\
\text { deconstructive } \\
\text { approaches; mainly } \\
\text { qualitative methods }\end{array}$ \\
\hline
\end{tabular}

${ }^{a}$ Adapted, modified, and extended from Guba and Lincoln (1994), Heron and Reason (1997), and Lincoln et al. (2011)

\subsection{1 (Post-)Positivist Paradigm}

Positivism and its successor, post-positivism, view the world as external to humans and independent of human experience. This view relies on the existence of reliable knowledge about the world that research strives to gain. In this perspective, there is a world independent of human experience, containing objects which behave in accordance with a set of natural laws. Positivist researchers can discover knowledge about these real things (knowledge that is certain, valid, and accurate), and determine the mechanisms and relations governing their behavior, through the use of the scientific method of reason, logic, and empirical inquiry (that is, experimentation and measurement of what can be observed). As there are many critical human phenomena that are not observable (e.g., mathematical thinking), post-positivists reject the positivist position that what can be studied is limited to the observable. Post-positivists are similar to positivists in that they believe the social world, like the natural world, can be studied in a value-free way that provides causal explanations for phenomena (Phillips and Burbules 2000). However, they differ from positivists in their belief that researchers should base claims regarding truth on probability rather than certainty. 
In both a positivist and post-positivist view, researchers strive for uncovering a single view of reality, a reality that is separated from the mind: the rational researcher can come to know the objective world by employing analytical thought and experimental methods. This is the cornerstone of a modern worldview concerned with objectivity, prediction, generalizability, linearity, and absolute truth (Harvey 1990).

Ontology Post-positivists hold that the world is real, is structured, and that this structure can be modeled. The positivists hold that a 'real' reality exists and that it is the researchers' job to discover that reality (naïve realism) (Guba and Lincoln 1994). Post-positivists concur, but add the qualification that reality can merely be known imperfectly because of the human limitations of researchers (critical realism) (Maxwell 2012). Therefore, researchers can discover reality only within a certain degree of probability. By eliminating alternative explanations for phenomena, they can strengthen existing theories that account for these phenomena, but never prove them beyond doubt.

Epistemology (Post-)positivists hold that there is an objective reality that researchers are expected to 'mirror' or 'replicate' in their models and theories. The role of research is to discover or uncover the real world and its structure. This position assumes that knowledge about the world is (or should be) objective and scientific findings can be determined reliably and validly, given that biases and values of the researcher and others involved in the research process are eliminated.

Axiology The (post-)positivist paradigm regards knowing the 'truth' in propositional form as an end in itself — and as the only end in itself (Lincoln et al. 2011). The role of the researcher is to be as objective as possible in order to ensure that scientific findings are obtained through a neutral process; that is, the research process is seen as largely apolitical and separate from a world of individual and group interests. The researcher has an ethical obligation to conduct research that is intellectually honest, suppresses personal bias, and avoids harm. Such research should entail careful collection and accurate reporting of data, as well as candid evaluation of the limitations of the study.

Methodology In general, researchers in this paradigm assume that they can obtain an accurate portrait of the 'true' nature of reality through the scientific methods of reason, logic, and empirical inquiry. The research designs used to accomplish this goal are largely deductive, with an emphasis on determining which variables explain or predict outcomes for a phenomenon of interest. Positivists borrow their experimental methods from the natural sciences. Post-positivists, in contrast, modify these methods in order to apply them to people, developing quasi-experimental methods. These predominantly quantitative methods privilege experimental, randomized-sample, hypothesis-testing studies. 


\subsubsection{Interpretive Paradigm}

The interpretive paradigm (or constructivist paradigm) views all meaning, including the meaning of research findings, as fundamentally interpretative. This paradigm assumes that all knowledge and meaning is constructed by those active in the research process (including participants and observers) and that researchers should attempt to understand the complex world of lived experiences from the viewpoint of those who live it (Schwandt 2000). The interpretive paradigm emphasizes that research is a product of the theories and values of researchers and cannot be independent of them. As Schoenfeld (2007) underlined: "One's explicit or implicit theoretical biases frame what one looks at, how one characterizes it, how one analyzes it, and how one interprets what one has analyzed" (p. 93).

Ontology Interpretivists reject the notion that there is one 'real' reality that can be known, but take a relativistic stance: that is, reality is a social construction that is experienced subjectively by different individuals. As there might be multiple socially constructed realities, "truth is the best-informed construction about which there is presently consensus" (Galbraith 1993, p. 74). Researchers in this paradigm try to understand the knowledge of others, as the others perceive it. In its most trivial version, interpretivism (or constructivism) takes the stance that the mind is active, not passive, in the construction of meaning and knowledge (von Glasersfeld 1995). Interpretivists do not so much discover knowledge but construct it.

Epistemology As there are multiple possible versions of reality (depending on the perspectives and values of individuals) in the interpretive paradigm, this paradigm replaces the concept of objectivity that is prominent in the (post-)positivist paradigm with the acknowledgement of subjectivity, inter-subjectivity, and live truth (i.e., truth in human terms) (Ernest 1998). The interpretive paradigm "challenges the traditional projection of epistemology, that of identifying a universal method for determining whether a particular theory or conceptual scheme matches or corresponds with external reality" (Cobb 2007, p. 10). The goal instead is, "to identify the variety of constructions that exist and bring them into as much consensus as possible" (Guba 1990, p. 26).

Axiology Interpretivists concern themselves with the meaning people derive from social interaction (Bryman 2016). The interpretive paradigm recognizes that experience is shaped by culture and context and filtered through individuals, and that there is not a singular reality that can be captured through research. Thus, multi-perspectival knowing is valuable as a means for balancing representations of diverse views. Interpretivists differ from (post-)positivists in that their model of 'reality' is contextual and situational. As such, alternative criteria are used to assess the validity of results, such as trustworthiness and authenticity.

Methodology In order to obtain contextual knowledge and to create a shared sense of reality, researchers in this paradigm typically use inductive research designs, which provide opportunities for findings to reflect context-specific, constructed meanings. Ethnography, case studies, and mostly qualitative forms of inquiry are used in this paradigm, with attempts made to better interpret meaning by 
obtaining, comparing, and contrasting multiple perspectives. The resultant exchange of conflicting ideas forces the reconsideration of previous positions and assists in the triangulation of multiple viewpoints (Ernest 1998).

\subsubsection{Transformative Paradigm}

The transformative paradigm (or critical paradigm) arose in response to the historical disadvantage, oppression, or discrimination faced by individuals belonging to minority groups, and seeks the intellectual, ideological, and spiritual liberation of such individuals (Tyson 2015). As such, it centers on the lives and experiences of those who experience oppression, discrimination, or inequality, including the following: women; people of color; immigrants; indigenous and postcolonial people; lesbian, gay, bisexual, transgender, and queer individuals; members of minority religious groups; and people with disabilities. Transformative researchers place priority on empowering those without power to bring about social transformation (see Horkheimer 1972; Mertens 2009).

The philosophical basis of the transformative paradigm is diverse, reflecting multiple approaches, theories, and positions represented in that paradigm, such as critical theory, critical race theory, feminist theory, queer theory, disability theory, and Indigenous theory (see Tyson 2015). For instance, feminist theory studies the systems and means employed by one group of people to structure and legitimize their domination of another group of people, and the strategies employed by the latter to resist this domination (see Hesse-Biber 2014; Lather 1991). Kaiser and Rogers (1995), drawing on McIntosh's (1983) phase theory of curriculum reform, argued for "loosen[ing] curriculum from a male-dominated, Eurocentric world view and to evolve a more inclusive curriculum to which all may have access" (pp. 1-2). On the other hand, queer theory challenges the binary notions of male and female that facilitate dichotomous conceptions of gender and sexual identity (see Dodd 2009; Mertens et al. 2008).

Ontology Similar to the interpretive paradigm, the transformative paradigm recognizes multiple versions of what is perceived to be real. However, those working within a transformative paradigm argue that "those working within an interpretative framework are too passive in that the framework itself is not critically examined for distortion and bias, i.e., crucial problems of conflict and change, are passed by through the acceptance of existing reference points" (Galbraith 1993, p. 76). That is, the transformative paradigm stresses that accepting different perceptions of reality as equally legitimate is dangerous, because it ignores the damage done by the social, political, cultural and economic factors that help privilege one version of reality over another. Besides, the transformative ontological position emphasizes that what seems 'real' may instead be an abstraction that was reified due to the influence of social and historical factors. Thus, before accepting something as 'real', those using the transformative paradigm critically examine that thing's role in perpetuating oppressive social structures and policies. 
Epistemology The transformative epistemological assumption centers on the meaning of knowledge, as viewed through a variety of cultural lenses, and the power issues involved in determining what knowledge is legitimate. Objectivity in the transformative paradigm is achieved by reflectively examining the values and social positions implicit in research questions, hypotheses, and definitions.

Axiology The transformative paradigm emerged as a consequence of dissatisfaction with research conducted within other paradigms, which was perceived to be irrelevant to, or a misrepresentation of, the lives of people who experience oppression, discrimination, or inequality. Valuable research in this paradigm is defined by its fostering of social justice and human rights, and the role of a researcher is to be an agent of prosocial change. Transparency and reciprocity are essential principles of the axiological position in the transformative paradigm. An explicit connection is made between the process and outcome of research and the fostering of a social agenda.

Methodology Transformative researchers use a diversity of methodologies to understand and analyze the experiences of study participants. Many use qualitative methods such as critical hermeneutics, as well as reflexive and deconstructive ethnography (see Kincheloe and McLaren 2002): critical hermeneutics seeks to understand how research works to maintain existing power relations and reflexive and deconstructive ethnography seeks "to free the object of analysis from the tyranny of fixed, unassailable categories and to rethink subjectivity itself as a permanently unclosed, always partial, narrative engagement with text and context" (Kincheloe and McLaren 2002, p. 121).

While some researchers working within this paradigm use quantitative and mixed methods, they stress the importance of being cautious in following existing methods to avoid racist, sexist, or otherwise biased results. Despite some variety, a common theme in transformative methodology is the inclusion of diverse voices from the marginalized. This inclusion takes the form of the involvement of participants in all stages of the research process, including planning, conducting, analyzing, interpreting, using, and benefiting from research.

\subsection{Ways of Dealing with Different Paradigms}

Traditional approaches in mathematics education have produced valuable but partial insights into critical issues in mathematics education, primarily because they have been grounded almost exclusively in the tenets of a narrow set of paradigmatic perspectives. Schoenfeld (2007) stated that around the mid-1970s, "the field's primary research methods (in the United States, at least) were statistical, but their use was often unsophisticated, and the field as a whole suffered from a reductive form of what has been called 'science envy"' (p. 103). Nowadays, however, the field recognizes that the use of any single paradigm produces too narrow a view to reflect the multi-faceted nature of the issues and phenomena under consideration. Over the past decades, mathematics education has increasingly veered away from 
modernist worldviews (in particular the (post-)positivist paradigm) toward post-modernist worldviews (in particular the interpretive and transformative paradigm) (Ernest 1998). This shift from modernist worldviews to post-modernist worldviews have resulted in a dynamic field, with a growing body of research from diverse, often contentious theoretical and philosophical positions that may enrich understandings of the complexity and the diverse concerns of mathematics education.

Increasing recognition and acknowledgment of the uncertainty and fluidity of knowledge are energizing the so-called 'paradigm debate' (see Gage 1989), fueling arguments over the superiority of certain paradigms as well as the commensurability (or incommensurability) and permeability (or impermeability) of paradigms (Cobb 2007; Lincoln et al. 2011). As the paradigm debate continues, education research appears increasingly fragmented and reflexive. Mathematics education offers a case in point. The field has become marked by numerous, deep-seated divisions, illustrated by dichotomous conceptualizations concerning mathematics (e.g., Platonism versus constructivism), mathematical meaning (e.g., referential versus shared; universal versus contextual; objective versus subjective), knowledge (e.g., formal versus intuitive; stable versus emergent; hierarchical versus decentralized), knowledge development (e.g., the ascension from the concrete to the abstract versus the ascension from the abstract to the concrete), and the unit of analysis (e.g., the individual versus the collective; the cognitive versus the social), among many others. Steen (1999) remarked that mathematics education is "a field in disarray, a field whose high hopes for a science of education have been overwhelmed by complexity and drowned in a sea of competing theories" (p. 236).

Mathematics education researchers have begun to explore strategies for dealing with the increasing multiplicity and diversity of theories in mathematics education (Bikner-Ahsbahs and Prediger 2014; Prediger et al. 2008). These efforts have indicated that at times different lenses might offer alternative perspectives of the phenomenon under consideration and at times fundamentally new viewpoints are needed to account for these different lenses (see Presmeg 2018, p. 281). Though the field has made substantial progress in coping with the diversity of theories, ways of dealing with different paradigms have been underexplored, and the benefits of examining a research problem from multiple paradigms seem to have not been explicitly investigated yet. This section puts forth three modes of thinking for dealing with various paradigms (and their respective philosophical assumptions) in mathematics education research: dualistic thinking, dialogical thinking, and dialectical thinking. Certainly, this is not an exhaustive list of modes of thinking concerning various paradigms. In fact, researchers in mathematics education, including Gravemeijer (1994), Lester (2005), and Cobb (2007) explicated that we often act as bricoleurs (in the sense of Lévi-Strauss 1966), by adopting ideas from a variety of theoretical sources and paradigms - in a variety of complex and at times conflicting ways - to conform to our intentions and own biases, an approach that cannot be easily subsumed under any of the three modes of thinking presented here. 


\subsubsection{Dualistic Thinking: Toward an Oppositional Standpoint}

The now-ubiquitous diversity of philosophical bases underpinning mathematics education research proliferates and polarizes paradigms, biasing researchers against opposing standpoints, and framing debates in terms of pairs of opposites, such as objectivity versus subjectivity and world versus mind. (Post-)positivist, interpretive, and transformative stances are often framed as competing paradigms from which one must choose. Dewey (1938/1997) reminded us:

\section{Mankind likes to think in terms of extreme opposites. It is given to formulating its beliefs in} terms of Either-Ors, between which it recognizes no intermediate possibilities. (p. 17)

Perhaps because of our predisposition "to think in terms of extreme opposites" (Dewey 1938/1997, p. 17), we are likely to look at the relationship between fundamental philosophical assumptions underpinning different paradigms as poles of an 'either-or' opposition. Such an oppositional standpoint encourages dualistic thinking that follows either-or logic for cognizing phenomena in the world. Such dualistic thinking compels researchers (by comparison, opposition, and differentiation of poles) to choose one paradigm while disregarding other paradigms as irrelevant. It prioritizes one side of a dualism (e.g., subjectivity over objectivity) and consequently takes a rather restricting frame of reference (e.g., mind over matter). It champions one-sidedness in the research process. For example, if one maintains that the world is real, one disregards the importance of the mind for the construction of reality, yielding a positivist position. On the other hand, if one thinks the mind determines what is real, one disregards the importance of the world in a similar way, favoring a relativist viewpoint, which is presupposed, for example, in the interpretive position. Either position commits itself to reductionism and determinism: a positivist position assumes that what dictates reality is the world itself, while an interpretive position advocates an individual's mind as the determinant of what is real.

\subsubsection{Dialogical Thinking: Toward a Pluralistic Standpoint}

An either-or logic that prioritizes one side of a dualism and marginalizes the other, fails to account for the complexity of reality. Accounting for the complexity of reality requires a pluralistic view that offers a "metaphysically perspicuous" approach (Turner 2010, p. 8).

In contrast to dualistic thinking, which follows either-or logic, dialogical thinking follows 'both-and' logic, in which two or more seemingly opposing perspectives can co-exist. This is not to say that dialogical thinking conflates or integrates different paradigms existing in the field; instead, dialogical thinking 
facilitates an interplay between paradigms, accentuating their differences and interconnections and fostering an appreciation of how paradigm insights and limitations are most apparent from opposing views. This sort of interplay of paradigms relates to multi-paradigm inquiry, in which different paradigm lenses are employed to cultivate diverse insights and contrast their various representations (see Gioia and Pitre 1990; Lewis and Grimes 1999). ${ }^{2}$ Lewis and Keleman (2002), for instance, stressed: "Multi-paradigm researchers apply an accommodating ideology, valuing paradigm perspectives for their potential to inform each other toward more encompassing theories" (p. 258).

Researchers might use various paradigms (including their respective foci and methods) to collect, analyze, and interpret data for recognizing complexities involved in, and acknowledging multiple understandings of, phenomena under consideration (see Lewis and Grimes 1999). By using paradigms other than their usual paradigm, a researcher might unfreeze and liberate initial assumptions, and eventually foster more creative and comprehensive insights as they continuously elaborate on and question previous analyses.

Whereas use of a single paradigm can produce a valuable but narrow view, multi-paradigm inquiry can generate multi-faceted accounts that portray the complexity and ambiguity of phenomena in mathematics education-accounts that reveal different yet interwoven facets of these phenomena.

Dualistic thinking fosters belief in an either-or dichotomous relationship to explain phenomena and ignores the possibility that facets of seemingly opposing accounts may be dependent on one another. Dialogical thinking, in contrast, might foster a more comprehensive portrayal of tensions and interdependencies, one that reflects complexity, plurality, and paradox - preventing researchers from falling into one-sided and partial claims about knowledge.

\subsubsection{Dialectical Thinking: Toward an Emerging Standpoint}

Dualistic thinking sidesteps paradoxes by privileging one side of a dualism, and dialogical thinking preserves conflicts between fundamental philosophical assumptions in order to grasp the disparate yet complementary focal points. Dialectical thinking, as suggested here, reconciles paradoxes to arrive at a richer and more comprehensive view of phenomena under consideration.

Lincoln et al. (2011) asked: "Are paradigms commensurable? Is it possible to blend elements of one paradigm into another, so that one is engaging in research that represents the best of both worldviews?" (p. 174). It is assumed here that paradigms (and their respective philosophical assumptions) can be blended to

\footnotetext{
${ }^{2}$ Researchers in the field of organizational theory use multi-paradigm approaches to capitalize on the strengths of different paradigms, in areas such as the formation of research questions, determination of methods, and analysis of validity of data.
} 
provide novel insights and understandings that were not evident in each isolated paradigm. As Tall (2013) indicated:

[...] frameworks may benefit from a broader theory that is a blend of both, explicitly revealing the nature of aspects that are supportive in some contexts yet problematic in others, yet at the same time, these aspects may blend together so that an apparent dichotomy has the potential to offer new insights. (pp. 410-411)

Blending $^{3}$ is a high level of coordinating paradigms (or their underlying philosophical assumptions) that does not imply synthesis or unification, but instead seeks to transcend dualisms. This is the level of coordinating perspectives that diSessa et al. (2016) described as 'deep synergy':

[the level] at which things pass beyond being 'interesting' to being 'fundamental for the field' [...], where the intellectual support for at least some of the most important ideas comes from both perspectives. This is the regime where retaining the identity of the two perspectives begins to become questionable. Genuinely new intellectual territory has been reached that is not construable from within only one perspective. (p. 5)

Blending is considered here as a rich resource for dealing with different paradigms that provides a productive way of producing novel insights that may not be manifest in the original paradigms. The goal is to arrive at an account that would make it possible to link diverse paradigms without reducing one to the other. What is important here is the recognition that different paradigms might have conflicting philosophical assumptions, but those conflicting assumptions can contribute to the blend, with the resulting blend being a worldview of higher explanatory power, flexibility, and greater insight.

In the following section, such a worldview is outlined: this worldview emerges from blending the modernist and post-modernist worldviews.

\subsection{Blending Modernism and Post-modernism: Towards an Emerging Paradigm}

The modern versus post-modern duality can be re-conceptualized as a blend of these two worldviews, forming a new worldview, one that has different, but related, underlying assumptions. The next two subsections explore such a blend with

\footnotetext{
${ }^{3}$ The term 'blending' has its origin in the work of Fauconnier and Turner (2002) on 'conceptual blending', who built a detailed framework of blending knowledge domains, where new elements result in the blend that were not evident in either domain on its own. According to Fauconnier and Turner (2002): "In conceptual blending, frames from established domains (known as inputs) are combined to yield a hybrid frame (a blend or blended model) comprised of structures from each of the inputs, as well as unique structure of its own" (p. 115). Turner (2014) specified that "[t]he blend is not an abstraction, or an analogy, or anything else already named and recognized in common sense. A blend is a new mental space that contains some elements from different mental spaces in a mental web but that develops new meaning of its own that is not drawn from those spaces. This new meaning emerges in the blend" (p. 6).
} 
respect to an ontological opposition (mind-world duality) and an epistemological opposition (objectivity-subjectivity duality) prevalent in the literature.

\subsubsection{Beyond Ontological Opposites: Transcending the Duality of Mind and World}

Modernism advocates a viewpoint in which the world surrounding us is seen as independent of our thought, a position that conflicts with post-modernism, which asserts that there is nothing but the constructions of our minds. A fundamental problem of the objective mind of modernism is that it cannot acknowledge that the ground, on which it stands to frame the world, is its own creation. It confuses the given world with the worldview it has generated for interpreting the given world. A basic problem with the subjective mind of post-modernism, on the other hand, is that it both allows any grounds as valid because it proposes a multiplicity of realities but offers no way to distinguish which is more legitimate. It confuses relative truth with nihilistic skepticism (Heron and Reason 1997): it postulates that because no ground is final, no ground has any claim to truth. While these perspectives help us in seeing the strengths and limitations of each of the paradigms, they do not help us in moving beyond the confusion they have produced. The alienation from experience created by the separation of mind and world is compounded when the world is reduced to multiple relativist constructions. Starting from this confusion, we can blend various aspects of modern and post-modern worldviews that are usually kept separate.

Such a blend accepts that there is a given world that the human mind actively interacts with (Skolimowski 1994). Mind and given world are engaged in a co-creative interaction so that what emerges as reality is an artifact of a complex, on-going interaction between the given world and the way mind engages with it (see Abram 1996; Heron and Reason 1997). Such a view seems to share certain aspects with Radford's (2013) theory of objectification. It shares the assumption that 'objective knowledge' exists independently of each one of us and that we meet what is other. However, while Radford (2013) emphasizes the idea that we objectify what meets (or objects) us, the view advanced here is that we do not only meet or objectify the other, but we also actively shape the other in mutually influencing ways: we shape the other and the other shapes us. This co-shaping brings about a subjectively articulated world, whose objectivity is relative to how the knower shapes it. Reality is subjective-objective, always called into being and shaped by the complex participation of the knower in what is known (see Reason 1998). 
This ontology is thus subjective-objective: "It is subjective because it is only known through the form the mind gives it; and it is objective because the mind interpenetrates the given cosmos which shapes it" (Heron 1996, p. 11). ${ }^{4}$

\subsubsection{Beyond Epistemological Opposites: Transcending the Duality of Objectivity and Subjectivity}

Modernism seems trapped in a Cartesian epistemology, a position in which our representations must conform to an objective world in order to constitute knowledge. This objectivity derives from the Enlightenment perspective for knowledge of the physical world, which is postulated to be separate and distinct from those who know. Kant (1787/2003) set out to reverse these assumptions, arguing we should see any possible object as having to conform to conditions of our knowledge before it can become an object for us. Thus, from a post-modernist perspective, knowledge cannot be separated from the knower, but is instead rooted in the knower's mental construction of that world. In post-modernism, the relativist concept of (socially constructed) reality leads to a subjectivist view of epistemology, in which individuals construct multiple (even competing and contradicting) realities.

Modernism and post-modernism struggle to maintain the balance between objectivity and subjectivity, and thus encounter the paradox of seeing objective subjectivity (or subjective objectivity). The blended view overcomes the epistemological limitations of modernism and post-modernism: reality is not pre-given or deterministically pre-defined but co-created. With the view of humans being an integral part of the world, the mind is meeting given reality through complex participating in its being, and the mind makes its world by meeting the given (see Abram 1996). Thus, knowledge is co-created by mind and environment.

Such a view agrees with post-modernist perspectives that it is impossible to give any definitive account of what exists: this view recognizes the subjective articulation of being in the world and accepts that our knowing is from a particular perspective - authentic and valuable but also restricted and biased. In this view,

\footnotetext{
${ }^{4}$ One might misunderstand these assertions, confusing this view with mentalistic or representationist approaches in which individuals construct internal representations of external representations. Though the view advocated here suggests that what can be known about an objective world is always known as a subjectively articulated world, it differs from mentalistic or representationist approaches in at least three critical characteristics: (1) it views the individual as an integral part of the world rather than isolated and against matter (or the 'outer world'), (2) it views individuals as self-determining rather than being determined by the 'outer world', and (3) it acknowledges rather than denies individuals in the creation of their world. It views the world as a 'living whole', a "complex system of interrelated entities of which we are part" (Reason 1998, p. 42). The notion of world as a living whole emphasizes that the given world that surrounds us is complex and dynamic. As such, not only 'the subjective' but also 'the objective' evolve and change over time, in the interaction with the mind. Such a view echoes Burger and Starbird's (2005) suggestion to construe disciplines such as mathematics as "a living, breathing, changing organism" (p. xi).
} 
an individual is critically reflective to the ground on which she or he stands; as echoed in what Torbert (1987) called a reframing mind that "continually overcomes itself, divesting itself of its own presuppositions" (p. 211).

\subsection{Reflections and Further Considerations}

Paradigms offer distinct, yet limited, insights into phenomena under consideration; they are contestable and provisional accounts that reveal certain facets of phenomena while overlooking others. Different paradigm lenses might contribute various, at times opposing and at times complementary, understandings. Taking a critical stance toward one's own underlying (and often taken-for-granted) assumptions is vital because "what we know of as 'reality' is an active projection of our own cognitive structure [...] we see the world in terms of ourselves" (Brocklesby 1997, p. 195).

Paradigm insights and biases are most recognizable from opposing viewpoints. Section 27.2 specified sets of fundamental philosophical assumptions used to delineate major paradigms underpinning much of mathematics education research, namely the (post-)positivist paradigm, the interpretive paradigm, and the transformative paradigm. By making opposing views and tensions explicit, one might distinguish the value and constraints of different paradigm lenses, identify unnoticed anomalies, and recognize how each lens distorts the phenomena observed and explanations proffered. Reflecting on the focus and limitations of different paradigm lenses may encourage researchers to "question, possibly for the first time, the veracity of the claim that the social consensus surrounding a paradigm's body of knowledge somehow represents proof of the truth" (Brocklesby 1997, p. 200). Such a critical reflection opens space for questioning, valuing, and including alternative paradigms in the research process. Cobb (2007) remarked that, "in coming to understand what adherents to an alternative perspective think they are doing, we develop a more sensitive and critical understanding of some of the taken-for-granted aspects of our own perspectives" (p. 32).

Section 27.3 outlined various potential ways for dealing with alternative paradigms, such as the following: privileging one side of a dualism; taking a multi-paradigm approach that aims to generate multi-sided accounts reflecting complexity, paradox, and ambiguity; and blending opposing positions to arrive at an expanded view that transcends dualisms. The intention was not to argue that the field should aim for conflation, integration, synthesis, or unification of competing paradigms. Instead, this chapter argued that phenomena and issues in mathematics education should be considered from a multi-paradigm perspective, and that paradigms could be blended to account creatively for a multi-faceted reality that is "in perpetual flux and transformation and hence unrepresentable through any static conceptual framework or paradigm of thought" (Chia 1996, p. 46). As Kilpatrick (1993) reminded us, "researchers in mathematics education should never become 
wedded to a single approach, epistemology, paradigm, means of representation or method. All are partial and provisional, none can tell the whole story" (p. 17).

It is suggested here that it is critical to hold a pluralist view when it comes to "understand[ing] the balancing of the complex human worlds involved in mathematics education" (Presmeg 1998, p. 63). When we consider each paradigm as a valid perspective and hold, use, or blend various paradigms, we are better able to cope with the "dilemmas, tensions, and contradictions of mathematical classrooms" (Presmeg 1998, p. 63). To better understand the complexities, recognize the paradoxes, and appreciate the ambiguities of phenomena and issues in mathematics education, we must often embrace seemingly contradictory views about the world. Hence, Sect. 27.4 attempted to blend modernism and post-modernism to articulate an emerging paradigm that acknowledges the co-creative interaction between mind and world, recasting the subjectivity-objectivity divide by viewing the world as subjectively articulated, in that its objectivity is relative to how it has been shaped by the knower (see Heron and Reason 1997). Such an account promotes a different way of conceptualizing paradoxical tensions across paradigms, which acknowledges the interrelationships between oppositions.

Interrelating seemingly conflicting worldviews might eventually foster recognition of the viewpoints that alternative paradigms provide additional layers of meaning (Morgan 1983) and that tensions between paradigms act as sense-making heuristics (Lewis and Grimes 1999). Such a recognition might then give rise to the view that the multi-vocality, contested meanings, and paradigmatic controversies existing in our field are rich resources for emancipation-emancipation from being framed by a single worldview, from being subject to a single voice, and from being trapped by dualistic perspectives. Eventually, this might provoke a 'transforming in the being' of the researchers themselves (Mason 1998): "it is their questions that change, their sensitivities that develop, their attention that is restructured, their awarenesses that are educated, their perspectives that alter. In short, it is their being that develops" (p. 358).

It is hoped that this chapter might prove helpful in reframing researchers' stances toward research in mathematics education, shifting them from a search for 'the' truth to a search for more critical, multi-faceted understandings stemming from diverse and partial worldviews - understandings that acknowledge the diversity and interdependencies of theoretical accounts and that reflect the complexity, ambiguity, and conflicts experienced by different individuals in the research process and beyond.

\section{References}

Abram, D. (1996). The spell of the sensuous: Perception and language in a more than human world. New York, NY: Pantheon.

Bikner-Ahsbahs, A., Knipping, C., \& Presmeg, N. C. (Eds.). (2015). Approaches to qualitative research in mathematics education: Examples of methodology and methods. New York, NY: Springer. 
Bikner-Ahsbahs, A., \& Prediger, S. (Eds.). (2014). Networking of theories as a research practice in mathematics education. New York, NY: Springer.

Brocklesby, J. (1997). Becoming multimethodology literate: An assessment of the cognitive difficulties of working across paradigms. In J. Mingers \& A. Gills (Eds.), Multimethodology (pp. 189-216). New York, NY: Wiley.

Bryman, A. (2016). Social research methods (5th ed.). Oxford, UK: Oxford University Press.

Burger, E. B., \& Starbird, M. (2005). The heart of mathematics: An invitation to effective thinking. Emeryville, CA: Key College Publishing.

Chia, R. (1996). Organizational analysis as deconstructive practice. New York, NY: Walter de Gruyter.

Cobb, P. (2007). Putting philosophy to work: Coping with multiple theoretical perspectives. In F. K. Lester (Ed.), Second handbook of research on mathematics teaching and learning (Vol. 2, pp. 3-38). Greenwich, CT: Information Age Publishing.

Dewey, J. (1938/1997). Experience and education (Original published 1938 by Kappa Delta Pi). New York, NY: Touchstone.

diSessa, A. A. (1991). If we want to get ahead, we should get some theories. In R. G. Underhill (Ed.), Proceedings of the 13th Annual Meeting of the North American Chapter of the International Group for the Psychology of Mathematics Education (Vol. 1, pp. 220-239). Blacksburg, VA: PME-NA.

diSessa, A. A., Levin, M., \& Brown, N. J. (Eds.). (2016). Knowledge and interaction: A synthetic agenda for the learning sciences. New York, NY: Routledge.

Dodd, S. (2009). LGBTQ: Protecting vulnerable subjects in all studies. In D. M. Mertens \& P. E. Ginsberg (Eds.), The handbook of social research ethics (pp. 474-488). Thousand Oaks, CA: Sage.

Ernest, P. (1991). The philosophy of mathematics education. London, UK: Routledge.

Ernest, P. (1998). A postmodern perspective on research in mathematics education. In A. Sierpinska \& J. Kilpatrick (Eds.), Mathematics education as a research domain: A search for identity (pp. 71-85). Dordrecht, The Netherlands: Kluwer.

Ernest, P. (2012). What is our first philosophy in mathematics education? For the Learning of Mathematics, 32(3), 8-14.

Fauconnier, G., \& Turner, M. (2002). The way we think: Conceptual blending and the mind's hidden complexities. New York, NY: Basic Books.

Gage, N. L. (1989). The paradigm wars and their aftermath a "historical" sketch of research on teaching since 1989. Educational Researcher, 18(7), 4-10.

Galbraith, P. (1993). Paradigms, problems and assessment: Some ideological implications. In M. Niss (Ed.), Investigations into assessment in mathematics education (pp. 73-86). Dordrecht, The Netherlands: Springer.

Gioia, D. A., \& Pitre, E. (1990). Multiparadigm perspectives on theory building. Academy of Management Review, 15(4), 584-602.

Gravemeijer, K. (1994). Educational development and developmental research. Journal for Research in Mathematics Education, 25(5), 443-471.

Guba, E. G. (1990). The alternative paradigm dialog. In E. G. Guba (Ed.), The paradigm dialog (pp. 17-27). Newbury Park, CA: Sage.

Guba, E. G., \& Lincoln, Y. S. (1994). Competing paradigms in qualitative research. In N. K. Denzin \& Y. S. Lincoln (Eds.), Handbook of qualitative research (pp. 105-117). Thousand Oaks, CA: Sage.

Habermas, J. (1972). Knowledge and human interests. London, UK: Heinemann.

Harvey, D. (1990). The condition of postmodernity. Oxford, UK: Blackwell.

Heron, J. (1996). Co-operative inquiry: Research into the human condition. London, UK: Sage.

Heron, J., \& Reason, P. (1997). A participatory inquiry paradigm. Qualitative Inquiry, 3(3), 274 294.

Hesse-Biber, S. N. (Ed.). (2014). Feminist research practice: A primer. Thousand Oaks, CA: Sage. 
Higginson, W. (1980). On the foundations of mathematics education. For the Learning of Mathematics, 1(2), 3-7.

Horkheimer, M. (1972). Critical theory. New York, NY: Seabury Press.

Jablonka, E., Wagner, D., \& Walshaw, M. (2013). Theories for studying social, political and cultural dimensions of mathematics education. In J. Clements, C. Keitel, A. J. Bishop, J. Kilpatrick, \& F. K. S. Leung (Eds.), Third international handbook of mathematics education (pp. 41-67). Dordrecht, The Netherlands: Springer.

Kaiser, G., \& Rogers, P. (1995). Introduction: Equity in mathematics education. In P. Rogers \& G. Kaiser (Eds.), Equity in mathematics education: Influences offeminism and culture (pp. 1-10). London, UK: Routledge.

Kant, I. (1787/2003). Critique of pure reason (N. K. Smith, Trans.). New York, NY: St. Marin's Press.

Karmiloff-Smith, A., \& Inhelder, B. (1974/75). If you want to get ahead, get a theory. Cognition, 3 (3), 195-212.

Kelly, A. E., \& Lesh, R. A. (2000). Handbook of research design in mathematics and science education. Mahwah, NJ: Lawrence Erlbaum Associates.

Kilpatrick, J. (1993). Beyond face value: Assessing research in mathematics education. In G. Nissen \& M. Blomhøj (Eds.), Criteria for scientific quality and relevance in the didactics of mathematics (pp. 15-34). Denmark: Danish Research Council for the Humanities, Roskilde University.

Kincheloe, J. L., \& McLaren, P. (2002). Rethinking critical theory and qualitative research. In Y. Zou \& E. T. Trueba (Eds.), Ethnography and schools: Qualitative approaches to the study of education (pp. 87-138). Oxford, UK: Rowman \& Littlefield.

Kuhn, T. S. (1962). The structure of scientific revolutions. Chicago, IL: The University of Chicago Press.

Lather, P. (1991). Getting smart: Feminist research and pedagogy with/in the postmodern. New York, NY: Routledge.

Lester, F. K. (2005). On the theoretical, conceptual, and philosophical foundations for research in mathematics education. ZDM-The International Journal on Mathematics Education, 37(6), 457-467.

Lévi-Strauss, C. (1966). The savage mind. Chicago, IL: University of Chicago Press.

Lewis, M. W., \& Grimes, A. J. (1999). Metatriangulation: Building theory from multiple paradigms. Academy of Management Review, 24, 672-690.

Lewis, M. W., \& Kelemen, M. L. (2002). Multiparadigm inquiry: Exploring organizational pluralism and paradox. Human Relations, 55(2), 251-275.

Lincoln, Y. S., Lynham, S. A., \& Guba, E. G. (2011). Paradigmatic controversies, contradictions, and emerging confluences, revisited. In N. K. Denzin \& Y. S. Lincoln (Eds.), The Sage handbook of qualitative research (4th ed., pp. 97-128). Thousand Oaks, CA: Sage.

Mason, J. (1998). Researching from the inside in mathematics education. In A. Sierpinska \& J. Kilpatrick (Eds.), Mathematics education as a research domain: A search for identity (pp. 357-377). Dordrecht, The Netherlands: Kluwer.

Maxwell, J. A. (2012). The importance of qualitative research for causal explanation in education. Qualitative Inquiry, 18(8), 655-661.

McIntosh, P. (1983). Phase theory of curriculum reform. Wellesley, MA: Center for Research on Women.

Mertens, D. M. (2009). Transformative research and evaluation. New York, NY: Guilford.

Mertens, D. M., Foster, J., \& Heimlich, J. E. (2008). M or F? Gender, identity and the transformative research paradigm. Museums and Social Issue, 3(1), 81-92.

Morgan, G. (Ed.). (1983). Beyond method: Strategies for social research. Newbury Park, CA: Sage.

Niss, M. (2018). The very multi-faceted nature of mathematics education research. In E. Bergqvist, M. Österholm, C. Granberg, \& L. Sumpter (Eds.), Proceedings of the 42nd Conference of the International Group for the Psychology of Mathematics Education (Vol. 1, pp. 35-50). Umeå, Sweden: PME. 
Phillips, D. C., \& Burbules, N. C. (2000). Postpositivism and educational research. New York, NY: Rowman \& Littlefield.

Prediger, S., Bikner-Ahsbahs, A., \& Arzarello, F. (2008). Networking strategies and methods for connecting theoretical approaches: First steps towards a conceptual framework. ZDM-The International Journal on Mathematics Education, 40(2), 165-178.

Presmeg, N. C. (1998). Balancing complex human worlds: Mathematics education as an emergent discipline in its own right. In A. Sierpinska \& J. Kilpatrick (Eds.), Mathematics education as a research domain: A search for identity (pp. 57-70). Dordrecht, The Netherlands: Kluwer.

Presmeg, N. C. (2018). Communication, cooperation and collaboration: ERME's magnificent experiment. In T. Dreyfus, M. Artigue, D. Potari, S. Prediger, \& K. Ruthven (Eds.), Developing research in mathematics education: Twenty years of communication, cooperation and collaboration in Europe (pp. 276-286). New York, NY: Routledge.

Radford, L. (2013). Three key concepts of the theory of objectification: Knowledge, knowing, and learning. Journal of Research in Mathematics Education, 2(1), 7-44.

Reason, P. (1998). Toward a participatory worldview. Resurgence, 168, 42-44.

Rogers, P., \& Kaiser, G. (Eds.). (1995). Equity in mathematics education: Influences of feminism and culture. London, UK: Routledge.

Schön, D. A., \& Rein, M. (1994). Frame reflections: Toward the resolution of intractable policy controversies. New York, NY: Basic Books.

Schoenfeld, A. H. (1992). On paradigms and methods: What do you do when the ones you know don't do what you want them to? Issues in the analysis of data in the form of videotapes. The Journal of the Learning Sciences, 2(2), 179-214.

Schoenfeld, A. H. (2007). Method. In F. K. Lester (Ed.), Second handbook of research on mathematics teaching and learning (pp. 69-107). Greenwich, CT: Information Age Publishing.

Schoenfeld, A. H. (2008). Research methods in (mathematics) education. In L. D. English, M. Bartolini-Bussi, G. A. Jones, R. A. Lesh, B. Sriraman, \& D. Tirosh (Eds.), Handbook of international research in mathematics education (pp. 467-519). Mahwah, NJ: Erlbaum.

Schoenfeld, A. H. (2014). If you really want to get ahead, get a bunch of theories ... and data to test them. The Mathematics Enthusiast, 11(1), 7-40.

Schwandt, T. A. (2000). Three epistemological stances for qualitative inquiry: Interpretivism, hermeneutics, and social constructionism. In N. K. Denzin \& Y. S. Lincoln (Eds.), Handbook of qualitative research (pp. 189-213). Thousand Oaks, CA: Sage.

Sierpinska, A., \& Kilpatrick, J. (Eds.). (1998). Mathematics education as a research domain: A search for identity. Dordrecht, The Netherlands: Kluwer.

Skolimowski, H. (1994). The participatory mind. London, UK: Arkana.

Skovsmose, O. (1994). Towards a philosophy of critical mathematics education. Dordrecht, The Netherlands: Kluwer.

Sriraman, B., \& English, L. (Eds.). (2010). Theories of mathematics education. New York, NY: Springer.

Steen, L. A. (1999). Theories that gyre and gimble in the wabe. Journal for Research in Mathematics Education, 30(2), 235-241.

Stinson, D. W., \& Bullock, E. C. (2012). Critical postmodern theory in mathematics education research: A praxis of uncertainty. Educational Studies in Mathematics, 80(1-2), 41-55.

Tall, D. O. (2013). How humans learn to think mathematically. Exploring the three worlds of mathematics. Cambridge, UK: Cambridge University Press.

Torbert, W. R. (1987). Managing the corporate dream: Restructuring for long-term success. Homewood, IL: Dow Jones-Irwin.

Turner, J. (2010). Ontological pluralism. Journal of Philosophy, 107(1), 5-34.

Turner, M. (2014). The origin of ideas. Oxford, UK: Oxford University Press.

Tyson, L. (2015). Critical theory today (3rd ed.). New York, NY: Routledge.

von Glasersfeld, E. (1995). Radical constructivism: A way of knowing and learning. London, UK: Falmer Press. 
Open Access This chapter is licensed under the terms of the Creative Commons Attribution 4.0 International License (http://creativecommons.org/licenses/by/4.0/), which permits use, sharing, adaptation, distribution and reproduction in any medium or format, as long as you give appropriate credit to the original author(s) and the source, provide a link to the Creative Commons license and indicate if changes were made.

The images or other third party material in this chapter are included in the chapter's Creative Commons license, unless indicated otherwise in a credit line to the material. If material is not included in the chapter's Creative Commons license and your intended use is not permitted by statutory regulation or exceeds the permitted use, you will need to obtain permission directly from the copyright holder.

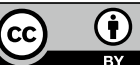

